\author{
Maria Loyola Opiela* \\ Lublin
}

\title{
Wkład kobiet w rozwój teorii i praktyki wczesnej edukacji w Polsce XIX i XX wieku
}

Rozwój pedagogiki przedszkolnej jest procesem przechodzenia od podstaw praktycznych do unaukowienia edukacji małego dziecka. Nie ma jednak dobrej edukacji bez dobrej pedagogiki, ani też dobrej pedagogiki bez dobrej praktyki. Na tej synergii teorii i praktyki kształtowały się podstawy wczesnej edukacji dziecka w obydwu wymiarach. Ukazanie wkładu kobiet $\mathrm{w}$ ten proces wymaga ukazania jego istoty i specyfiki w odniesieniu do doświadczeń dwóch minionych wieków.

W procesie kształtowania się pedagogiki przedszkolnej ważne jest określenie jej przedmiotu, gdyż to wokół niego koncentruje się rola i wkład kobiet $\mathrm{w}$ jej rozwój. Przedmiotem tym jest edukacja dziecka od urodzenia do czasu rozpoczęcia nauki w szkole. Przyjmujemy pojęcie edukacji, w którym wyróżnia się wychowanie i kształcenie. W kształceniu zaś nauczanie i uczenie się ${ }^{1}$. Pojęcie wczesnej edukacji obejmuje zatem harmonijny system oddziaływań uwzględniający działania opiekuńcze, wychowanie, uczenie i uczenie się, a wzorem dla jej instytucjonalnych form jest rodzina. Potrzeby i możliwości rozwojowe małego dziecka wymagają dla jego integralnego rozwoju głębokiej relacji z osobą wychowująca, dającą poczucie akceptacji

* S. dr hab. Maria Loyola Opiela jest adiunktem w Katedrze Pedagogiki Chrześcijańskiej Instytutu Pedagogiki Katolickiego Uniwersytetu Lubelskiego Jana Pawła II.

${ }^{1}$ Por. K. Rubacha, Edukacja jako przedmiot pedagogiki i jej subdyscyplin, w: Z. Kwieciński, B. Śliwerski (red.), Pedagogika, Warszawa 2009, s. 27. 
i bezpieczeństwa. Należy także określić cel i odpowiednie proporcje tych ogólnorozwojowych działań edukacyjnych.

W związku z tym tak ważnym i fundamentalnym dla całego życia osoby okresem rozwoju należy wskazać na model rodzinny i role pierwszych wychowawców - rodziców. Najkrócej możemy powiedzieć, że mężczyzna (ojciec, wychowawca) ochrania rodzinę od zewnątrz, a kobieta (matka, wychowawczyni) buduje ją od wewnattrz. Obydwoje, dopełniając się w swych rolach rodzicielskich i zawodowych, we właściwy sobie sposób angażują się dla dobra swej wspólnoty rodzinnej, narodowej czy religijnej. Na tym tle i w ścisłym z nim powiązaniem należy uwzględnić wkład kobiet zaangażowanych bezpośrednio i pośrednio w edukację małego dziecka. Wiele z nich pozostaje bezimiennych, ale bez ich zaangażowania w wychowanie małych dzieci, miłości do dziecka, twórczej wierności tradycji oraz tworzenia naturalnego środowiska wychowawczego i jego kultury w rodzinie i placówce edukacyjnej trudno mówić o pełnym ujęciu tematu.

Sięgając do doświadczeń z przeszłości, warto w kontekście współczesnych wyzwań spojrzeć na rolę kobiet, wskazaną przez Ludwika Posadzego, wyrażającego przekonanie Augusta Cieszkowskiego: „Miłosna natura niewiasty musi przyjść w pomoc naszemu choremu stuleciu, ona tylko może sporządzić lekarstwo na przywary społeczne. Tym lekarstwem będą ochrony"2. Tak określona rola kobiety i wartość wczesnej edukacji nic bowiem nie straciły na aktualności i znaczeniu.

\section{Kobieta w rolach matki, wychowawczyni, nauczycielki w rodzinie i społeczeństwie}

Wychowanie małego dziecka do końca XVIII wieku pozostawało wyłącznie zawierzone rodzinie, a w niej przede wszystkim matce. Nie można zatem pominąć jej roli w kształtowaniu tradycji wychowawczej jako podstawy dla refleksji teoretycznej nad wczesną edukacją. Dziecko urodzone w rodzinie szlacheckiej czy ziemiańskiej, często też u zamożnych mieszczan i inteligencji, powierzane było bonom i niańkom. Wybierając dla niemowląt opiekunki, kierowano się przede wszystkim ich doświadczeniem, wiedzą, a także sympatią dla dzieci. Zadania piastunek obejmowały nadzorowanie zajęć dziecka, jego nauczanie, począwszy od najprostszych czynności aż do

${ }^{2}$ L. Posadzy, Przedmowa, w: A. Cieszkowski, O ochronach wiejskich, Poznań 1922, s. XII. 
wpajania zasad dobrego wychowania. Innymi wymaganiami kierowano się wybierając niańkę dla niemowlęcia, innymi, szukając bony dla kilkulatka, a zawsze ważne było doświadczenie kobiety ${ }^{3}$.

W XIX-wiecznej Polsce, zakorzenionej w tradycji judeochrześcijańskiej, dominowały patriarchalne systemy społeczne, uznające naturalny dualizm płci i wynikający z niego podział ról. Kobieta w roli żony i matki budziła podziw i uznanie. Powszechne przekonanie o biologicznym podłożu i boskim porządku tych ról, uświęconym tradycyjną obyczajowością, zapewniało kobiecie wysoką pozycję w kulturze i tradycji polskiej ${ }^{4}$. $Z$ tego okresu znane są postacie kobiet wspierających rozwój ochronek dla dzieci - należą do nich między innymi Karolina Raczyńska, Jadwiga Sapieżyna, Cecylia Działyńska, Elżbieta Czartoryska.

Historycy kultury podkreślają wyjątkowość kultu kobiety - żony i mat$\mathrm{ki}-\mathrm{w}$ polskim patriarchalnym społeczeństwie. Nigdzie bowiem nie spotyka się

tak jednoznacznie określonego i zalecanego do naśladowania kobietom ze wszystkich stanów i warstw społecznych ideału kobiety i kobiecości. Kobieta w roli żony i matki zajmowała niekwestionowaną, wysoką pozycję społeczną. Był to ideał najbardziej trwały i oporny na zmiany. Tym zasadniczym rolom były podporządkowane wszystkie inne, związane z działalnością edukacyjną, kulturalną, społeczną, polityczną czy aktywnością zawodową

Także szeroko prowadzona przez siostry zakonne i kobiety z wyższych sfer działalność charytatywna wobec sierot i dzieci ubogich, mimo jej wyraźnie społecznego charakteru, z czasem przyczyniała się do pogłębiania wiedzy o wychowaniu dziecka, zmierzającej do unaukowienia. Ten proces rozpoczął się w drugiej połowie XVIII wieku, głównie za sprawą Komisji Edukacji Narodowej i podejmowanych przez nią dyskusji o człowieku i jego edukacji ${ }^{6}$. Istotne było tu odniesienie do natury, religii i historii, jako podstaw myślenia o edukacji człowieka.

${ }^{3}$ Por. P. Kanafocka, Polki w zaborze pruskim 1793-1918. Dwie przestrzenie edukacyjne, publiczna i prywatna, Warszawa 2012, s. 250-251.

${ }^{4}$ Por. D. Pauluk, Modele ról kobiety w podręcznikach do wychowania seksualnego, Kraków 2005, s. 18.

5 Tamże, s. 8.

${ }^{6}$ Zob. D. Waloszek, Pedagogika przedszkolna. Metamorfoza statusu i przedmiotu badań, Kraków 2006, s. 57. 
Podstawowym zadaniem kobiety było sprawowanie opieki nad dziećmi i domem oraz pomoc mężowi w pracach polowych. K. Jakubiak zauważa, że: „Jakkolwiek z prawnego i formalnego punktu widzenia głową rodziny od drugiej połowy XIX wieku pozostawał ojciec, to w rzeczywistości - jak wynika z wielu przekazów pamiętnikarskich i opinii publicystycznych - dominującą pozycję w rodzinie zyskiwała matka"7. Te tradycyjne role zostały poddane radykalnym przeobrażeniom dopiero $\mathrm{w}$ drugiej połowie XX wieku pod wpływem ideologii i praktyki socjalizmu, co następnie pogłębiły ideologie liberalne, docierające do Polski po przełomie społeczno-ustrojowym w 1989 roku. W zależności od aktualnej polityki państwa i warunków ekonomicznych pojawiał się na przemian ideał kobiety w rolach rodzinnych i zawodowych ${ }^{8}$.

Kobiety, chociaż przeważnie stanowiły jedynie tło ważnych wydarzeń jako żony, matki, córki, a ich działania ograniczały się w dużej mierze do sfery domowej, to w szczególny sposób i one tworzyły „wielką historię”. Ich niezastapiony wkład to wczesne wychowanie dzieci, organizacja środowiska wychowawczego w rodzinie, społeczna działalność oświatowa w środowisku, a w końcu metodyczne i naukowe zaangażowanie. Zawsze jednak praktyczne zorientowanie towarzyszyło nawet próbom teoretycznych rozwiązań i dominuje nadal w badaniach. To sprawiało, że ich organizowanie się, przy niedocenieniu znaczenia podstaw teoretycznych, przybierało formy kontynuacji tradycji bądź ulegania ideologiom i modom w dziedzinie propagowania obcych wzorców i koncepcji wychowawczych.

Pod koniec XIX wieku głos kobiet pochodzących z kręgów ziemiańskich stał się bardziej słyszalny, gdy założyły one Zjednoczone Koło Ziemianek (ZKZ), jedną z pierwszych na świecie kobiecą organizację zawodowogospodarczą zrzeszająca tysiące członkiń. Od początku istnienia koła dużą wagę przywiązywano do samokształcenia i doskonalenia się samych ziemianek, zarówno pod względem umysłowym, jak i moralnym. Organizowano liczne kursy, przede wszystkim dla córek ziemiańskich, które miały budzić w nich uczucia patriotyczne i przygotowywać do nienagannego kierowania domem i gospodarstwem oraz pracy z ludem. Mottem wszelkich działań było hasło „Z Bogiem i z Narodem”.

${ }^{7}$ K. Jakubiak, Postulowane wartości oraz wzorce życia i wychowania w rodzinie polskiej w XIX i poczatkach XX wieku, w: J. Gnitecki, J. Rutkowiak (red.), Pedagogika i edukacja. Wobec nadziei i zagrożeń wspótczesnych, materiały z III Ogólnopolskiego Zjazdu Pedagogicznego, Warszawa-Poznań 1999, s. 144.

${ }^{8}$ Zob. D. Pauluk, dz. cyt., s. 8. 
Z inicjatywy Cecylii Plater-Zyberkówny, aktywnej działaczki pedagogicznej i publicystki, w 1861 roku powstała szkoła gospodarstwa domowego dla młodych ziemianek. Dla dzieci chłopskich organizowano ochronki, gdzie pod okiem wyuczonej ochroniarki lub samych ziemianek uczyły się mowy ojczystej, wierszyków, piosenek, dbania o higienę, poznawały zagadnienia przyrodnicze i historyczne, rozwijały zdolności manualne. Do najbardziej zasłużonych działaczek ZKZ należały: Maria Kleniewska - założycielka organizacji, Maria Karczewska, Teresa Siemieńska, Julia Kisielewska, Maria Kretkowska, Maria Rodziewiczówna, a wśród członkiń honorowych Eliza Orzeszkowa, Maria Curie-Skłodowska9 .

Inną organizacją kulturalno-oświatową, której członkinie pomnażały wkład kobiet w rozwój wczesnej edukacji, była Polska Macierz Szkolna, założona na terenie Królestwa Polskiego w 1906 roku. Celem organizacji było krzewienie i popieranie oświaty w duchu chrześcijańskim i narodowym poprzez zakładanie i prowadzenie instytucji wychowawczo-oświatowych; ochronek i szkół różnego typu ${ }^{10}$. Działaczki PMS sprawdziły się jako nauczycielki na kursach dla nauczycieli, między innymi w dziedzinie wychowania przedszkolnego, które było przez nie zdominowane. Ich zadaniem było także „wychowywać swoje otoczenie” i kształtowanie „oblicza duchowego rodziny polskiej"11.

Postępujące zmiany znajdowały bardzo wyraźne odzwierciedlenie nie tylko w domowym wychowaniu dzieci, ale także w jego instytucjonalnych formach. Tworząca się nowa jakość wczesnej edukacji była związana z kształtującymi się teoretycznymi podstawami wychowania. Duży wpływ miały panujące aktualnie wzorce zachowań i praktyka pedagogiczna oraz ideologie. Na nich rozwijała się teoria wychowania przedszkolnego oraz jej metodyczny i organizacyjny wymiar. Zmieniające się elementy współtworzące model ról małżeńsko-rodzinnych kobiety, jakimi są treści traktujące o istocie, celach małżeństwa i rodziny, funkcjach kobiety żony i matki, zawsze dostarczały wzorów i doświadczeń bezpośrednio wpływających na

9 Zob. na ten temat artykuły w książkach: A. Jasińska-Janiak, K. Sierakowska, A. Szwarc (red.), Działaczki społeczne, feministki, obywatelki... Samoorganizowanie się kobiet na ziemiach polskich do 1918 roku (na tle porównawczym), t. 1, Warszawa 2008, s. 389-407; t. 2, Warszawa 2009, s. 117-131.

${ }_{10}$ W 1907 roku prowadziła 317 ochronek dla 14401 dzieci.

11 Por. J. Góralski, Miejsce i rola kobiety w Polskiej Macierzy Szkolnej (1905-1939), w: W. Jamrożek, D. Żołądź-Strzelczyk (red.), Rola i miejsce kobiet w edukacji i kulturze polskiej, Poznań 2001, s. 137-142. 
wczesny rozwój i wychowanie dziecka w rodzinie. Miejsce i pozycja kobiety w przyjętych modelach małżeństwa i rodziny zakorzenionych w określonej epoce były istotnym elementem rozwijającej się teorii wychowania przedszkolnego, które silnie powiązane jest $\mathrm{z}$ wychowaniem w rodzinie.

Współzależność ta między teorią i praktyką edukacji a modelem i stylem życia kobiet widoczna jest szczególnie w dwóch etapach ich przeobrażeń w XX wieku. W pierwszym etapie narzucony Polsce ustrój socjalistyczny z jego ideologia, określona polityka państwa wobec spraw i problemów kobiecych, masowe podejmowanie przez kobiety pracy zawodowej wpłynęły na modelowe i na rzeczywiste zmiany w sposobie pełnienia wyznaczonych im ról. W myśl obowiązującej ideologii pojawił się ujednolicony wzorzec osobowy, znoszący wszelkie dystynkcje pomiędzy płciami. W drugim przełomowym etapie zapoczątkowanym przez transformacje społeczno-ustrojowe po 1989 roku hasła tolerancji i pluralizmu, liberalizacja norm obyczajowych, antytradycjonalistyczny i indywidualistyczny charakter przeobrażeń doprowadziły do pojawienia się nurtów podważających lub negujących dotychczasowe role kobiety ${ }^{12}$, także jako matki, wychowawczyni czy nauczycielki.

Ważnym dla kształtowania praktyki wczesnej edukacji przez kobiety był występujący w drugiej połowie XIX wieku na ziemiach polskich rozwój żeńskich zgromadzeń zakonnych rodzimego pochodzenia. Celem wielu z nich było społeczne oddziaływanie, harmonijne i wielostronne, oraz opieka nad dziećmi w ochronkach. Charakterystycznymi, specyficznie polskimi aspektami był związek z ruchem emancypacyjnym i wyjątkową pozycją kobiety w społeczeństwie, pozbawionym samodzielnego bytu państwowego, aspekt społeczno-ekonomiczny działalności i silne zabarwienie patriotyczne ${ }^{13}$. Nowością były liczne inicjatywy zakonotwórcze kobiet. Przykładem są: Marcelina Darowska - współzałożycielka niepokalanek, Celina Borzęcka wraz z córką Jadwigą - założycielka zmartwychwstanek, Zofia Truszkowska - felicjanek, Kolumba Białecka - dominikanek, Franciszka Siedliska - nazaretanek, Maria Karłowska - pasterek, Bolesława Lament - misjonarek Świętej Rodziny. Podejmowały one prace zgodne z pilnymi miejscowymi potrzebami społecznymi, prowadziły między innymi sierocińce, przedszkola, ochronki. O ich znaczeniu wymownie pisze Józefa Karska - współzałożycielka nie-

${ }_{12}$ Por. D. Pauluk, dz. cyt., s. 8-9.

${ }_{13}$ Por. J. Kłoczowski, Zakony w Polsce (966-1972), w: Metody i źródła do badań z historii społecznej XIX i XX wieku, Lublin 1975, s. 9-36. 
pokalanek: „W żadnym kraju kobiety, samą już siłą rzeczy i wrodzonych zdolności, tyle wpływu, co u nas nie mają"14.

Powstałe w XIX wieku zgromadzenia zakonne miały ogromne znaczenie i czynny udział w całokształcie przemian społeczno-religijnych w naszym narodzie poprzez edukację nowych pokoleń począwszy od najmłodszych. Ideały życia reprezentowane przez ośrodki zakonne, wyrażające się w życiu i działalności sióstr, przenikały ich otoczenie i przemieniały je jakościowo. Szczególny, choć mało doceniany wkład tych zgromadzeń widoczny jest w praktycznej działalności opiekuńczo-wychowawczej i charytatywnej, poprzez którą dokonywało się wielorakie oddziaływanie na społeczeństwo. W literaturze $\mathrm{z}$ zakresu historii wychowania ${ }^{15}$ albo pomijano tę działalność milczeniem czy lakoniczną wzmianka, albo przedstawiano ją jako oderwaną od rzeczywistości. Dopiero na przełomie XX i XXI wieku zaczęto wskazywać udział zgromadzeń i ich założycieli w rozwoju wychowania przedszkolnego $^{16}$, a w ostatnich latach podjęto badania nad pedagogiami zgromadzeń zakonnych ${ }^{17}$, które obejmują również działaność w ochronkach i przedszkolach.

W ustawodawstwie państwowym, szczególnie w latach po II wojnie światowej, instytucjom opiekuńczo-wychowawczym i oświatowym prowadzonym przez zgromadzenia zakonne nie przyznawano praw do prowadzenia działalności, a nawet wprost jej zabraniano. Taka polityka władz państwowych w Polsce trwała praktycznie do lat osiemdziesiątych ${ }^{18}$.

${ }^{14}$ F. Koneczny, Święci w dziejach narodu polskiego, Kraków 1985, s. 250.

15 Por. M. Wróbel, Wychowanie przedszkolne w Polsce w latach 1918-1939, Wrocław 1967; J. Miąso, Historia wychowania w XX wieku, Warszawa 1986; Z. Bobrowska-Nowak, Historia wychowania przedszkolnego w Polsce, Warszawa 1978; Z. Marek, Rozwój teorii wychowania religijnego dziecka $w$ wieku przedszkolnym w Polsce w latach 1945-1990, Kraków 1994, s. 51-53.

${ }^{16}$ Zob. I. Adamek, Przygotowanie dzieci do szkoty w warunkach rozwijajacego się wychowania przedszkolnego na ziemiach polskich (druga połowa XIX wieku - 1918 rok), Kraków 1999; K. Olbrycht, Zarys systemu wychowania Urszuli Ledóchowskiej, Ząbki 2002; J. Draus, R. Terlecki, Historia wychowania, t. 2: Wiek XIX i XX, Kraków 2005.

17 Zob. J. Kostkiewicz (red.), Pedagogie katolickich zgromadzeń zakonnych. Historia i wspótczesność, t. 1, Kraków 2012; J. Kostkiewicz, K. Misiaszek (red.), Pedagogie katolickich zgromadzeń zakonnych. Historia i współczesność, t. 2, Kraków 2013, a tom trzeci jest w druku (zob. www.impulsoficyna.com.pl, w „zapowiedziach”).

18 Por. M. Opiela, Dynamika przemian działalności opiekuńczo-wychowawczej Sióstr Stużebniczek BDNP w ochronkach, Dębica 2011, s. 31-32. 


\section{Kobiety rozwijające i doskonalące metodykę wczesnej edukacji i kształcenie nauczycieli}

Na przestrzeni dwóch wieków rozwoju podstaw pedagogiki przedszkolnej należy dostrzec i dowartościować wkład polskich kobiet rozwijających i doskonalących metodykę wczesnej edukacji na podstawie różnych systemów i koncepcji. Odwołując się do własnych doświadczeń z dzieciństwa czy macierzyństwa, ważność wychowania małego dziecka postrzegały integralnie - w rodzinie i rozwijających się różnych formach przedszkolnych. Stąd wskazania dotyczące różnych aspektów wychowania, szczególnie moralno-religijnego, umysłowego i fizycznego w poradnikach, instrukcjach, czasopismach kierowanych do rodziców i wychowawczyń ochronek bądź służących ich kształceniu. Wśród autorek należy wskazać Anielę Szycównę, Jadwigę z Działyńskich Zamoyska, Izę Moszczeńską ${ }^{19}$, Marię Weryho, Stefanię M. Posadzową oraz wiele innych entuzjastek i działaczek społecznych przełomu XIX i XX wieku.

Reprezentatywnymi dla tego okresu były pisma: „Kółko Domowe” (1861-1864) Aleksandry Borkowskiej i Józefy Śmigielskiej, „Kronika Rodzinna” (1867-1915), „Opiekun Domowy” (1868), „Ognisko Domowe” (1883-1917) i wiele innych. Ogółem do wybuchu pierwszej wojny światowej ukazywało się ponad 50 tytułów pism rodzinnych (wraz z dodatkami do prasy ogólnej). W okresie międzywojennym przekształciły się w pisma pedagogiczne i poradnikowe kierowane do matek ${ }^{20}$.

Znaczący wpływ na doskonalenie treści i oddziaływań wychowawczych w XIX wieku wywarła pierwsza w Polsce autorka książek dla dzieci i młodzieży, Klementyna z Tańskich Hoffmanowa, pedagog, działaczka kulturalna w kraju i na emigracji. Dzięki starannemu wychowaniu domowemu uczyła się języka ojczystego na wzorach klasyków i znała kilka języków obcych, miała szeroką wiedzę o dziejach kultury polskiej. Podejmowała obronę mowy ojczystej między innymi w ujętych w atrakcyjnej formie dziennikar-

19 Por. K. Jakubiak, Edukacja rodziców w polskiej refleksji i praktyce pedagogicznej XIX i XX wieku - do 1939 roku, w: K. Jakubiak, A. Winiarz (red.), Wychowanie w rodzinie polskiej od schytku XVIII do połowy XX wieku, Bydgoszcz 2000, s. 115-122.

${ }^{20} \mathrm{http}$ //historia_kobiet.w.interia.pl/teksty/w-o-kob.htm (24.10.2013 r.). 
skiej Listach brata do siostry o języku polskim. W rozprawce pedagogicznej Pamiatka po dobrej Matce przez młoda Polkę, adresowanej do dorastających dziewcząt, podkreślała ich przyszłe obowiązki obywatelskie. Na łamach stworzonego przez nią pierwszego polskiego czasopisma dziecięcego „Rozrywki dla dzieci" ${ }^{21}$ publikowano między innymi wiersze, bajki, opowiadania dla dzieci, głównie o charakterze patriotycznym i wychowawczym. Prowadziła dział „Wiadomości mogące być matkom przydatne”, dbając o rodzinne wychowanie patriotyczne i moralne dzieci i młodzieży ${ }^{22}$. Publikowała w nim artykuły popularyzujące dzieje kultury polskiej: biografie znakomitych Polaków i Polek, opisy zabytków, opatrzone komentarzami historycznymi, ze zwróceniem uwagi na obecny stan kraju. Hoffmanowa pisywała także do pierwszego w Europie „Dziennika dla dzieci” o profilu wychowawczym. Mimo zakazu wprowadzania pism emigrantów na ziemie polskie, pod zaborami wydawała, głównie w Berlinie i Lipsku, serie opowiadań dla dzieci, książeczki o tematyce religijnej, a dla młodzieży opisy podróży zagranicznych. Fragmenty jej utworów włączano w XIX wieku i w okresie międzywojennym do dziecięcych czytanek i wypisów szkolnych ${ }^{23}$.

W Królestwie Polskim do propagowania systemu Fröbla przyczyniła się Teresa Pruszak-Mleczkowa, która w 1870 roku przy współpracy z A. Wiślickim otworzyła prywatne przedszkole. W tej placówce dla dzieci z zamożnych rodzin warszawskich prowadziła także kursy freblowskie dla wychowawczyń. Unowocześniając metody pracy przedszkola, wprowadzała wskazówki M. Pape-Carpantier, korzystała z najnowszej literatury dla dzieci. $\mathrm{W}$ ten sposób realizowała cele wychowania patriotycznego i społecznego, troszczyła się o rozwój fizyczny i psychiczny dzieci oraz wyrobienie w nich poczucia narodowego. Wzorując się na jej placówce i doświadczeniach, zakładano podobne ogródki freblowskie w innych miastach ${ }^{24}$.

Wiek XIX to okres rodzimych osiagnięć w dziedzinie wczesnego wychowania dzieci zainspirowanych przez A. Cieszkowskiego, E. Bojanowskiego czy A. Goltza, a realizowanych przez siostry zakonne oraz dzięki wspólnym inicjatywom kobiet. O szybki rozwój przedszkoli w Polsce i jakość prowadzonego w nich wychowania na przełomie XIX i XX wieku wal-

${ }^{21}$ Pamiqtka po dobrej Matce przez młodq Polkę została wydana w 1819 roku. Czasopismo Rozrywki dla dzieci ukazywało się w latach 1824-1828.

22 Por. K. Jakubiak, Edukacja rodziców, s. 123.

${ }^{23}$ Por. P. Kanafocka, dz. cyt., s. 104, 177-179.

${ }^{24}$ Por. Z. Bobrowska-Nowak, dz. cyt., s. 176-178. 
czyły działaczki zrzeszone w Polskim Towarzystwie Pedagogicznym w Sekcji Wychowania Przedszkolnego. Zajmowały się propagowaniem systemów wychowania przedszkolnego, rozwiązań metodycznych dostosowanych do możliwości i potrzeb rozwojowych dzieci oraz kształceniem zawodowym wychowawczyń. W tym celu przygotowywały podręczniki dla nauki ochroniarek, instrukcje, materiały metodyczne, przeznaczone także dla matek czy rodziców małych dzieci. Wśród nich wyróżniały się Maria Weryho-Radziwiłłowiczowa (1859-1944), Aniela Szycówna (1869-1921), Jadwiga Chrząszczewska (1870-1935), Maria Kretkowska (1863-1947), Zofia Żukiewiczowa, Zofia Bogdanowiczowa i wiele innych. Wtedy też powstały teoretyczne i praktyczne opracowania Stefanii Marciszewskiej-Posadzowej (1874-1955), s. Barbary Żulińskiej (1881-1962), Marii Jaworskiej, Natalii Cicimirskiej (1881-1959), Idy M. Schätzel, A. Gustowiczównej. Zaangażowane w metodykę pracy pedagogicznej działaczki wdrażały do praktyki najnowsze metody i pozostawiły po sobie pokaźny dorobek w postaci materiałów dydaktycznych i artykułów publikowanych w czasopismach pedagogicznych. Z publikacji i kursów korzystały także siostry zakonne prowadzące placówki przedszkolne.

M. Weryho-Radziwiłłowiczowa na przełomie XIX i XX wieku propagowała wychowanie przedszkolne, prowadziła kursy dla wychowawczyń oraz szeroką działalność społeczną, pedagogiczną i publicystyczną. Założyła seminaria dla ochroniarek i 30 przedszkoli służących za wzór dla nowo zakładanych, w których program obejmował różnorodne zajęcia wszechstronnie przygotowujące dziecko do późniejszej pracy w szkole ${ }^{25}$. Korzystała z zachodnich doświadczeń i rozwiązań organizacyjnych oraz systemów F. Fröbla, M. Montessori, O. Declory’ego w opracowaniu wskazówek metodycznych dla polskich ochron dostosowanych do potrzeb i możliwości rozwojowych dzieci ${ }^{26}$.

S. Marciszewska-Posadzowa była aktywną organizatorką i kierowniczką instytucji przedszkolnych, wychowawczynią i nauczycielką metodyki na kursach i seminariach ochroniarskich. Swoje poradniki metodyczne publikowała w serii „Biblioteka wychowania przedszkolnego”, która „obejmowała potrzeby wychowawcze dziecka od zarania życia aż do chwili pójścia

25 I. Adamek, Przygotowanie, s. 83.

${ }^{26}$ Zob. H. Raczek, Maria Weryho-Radziwitłowiczowa jako organizatorka wychowania przedszkolnego na ziemiach polskich przełomu XIX i XX wieku, w: W. Jamrożek, D. Żołądź-Strzelczyk (red.), dz. cyt., s. 81-86. 
do szkoły"27. W 17 zeszytach uświadamiała rodzinie jej ważne zadania wychowawcze, matkom przedstawiała ich przywilej względem dziecka i doradzała wychowawczyniom, które w żłobkach i ochronkach zastępowały matki. W swojej koncepcji wychowania przedszkolnego odwoływała się do rodzimych koncepcji i pedagogów. Zalecała stworzenie odpowiednich warunków dla rozwoju samodzielności i aktywności dziecka, które traktowała podmiotowo. Bardzo ważnym wymiarem wielostronnej edukacji dziecka było wychowanie moralno-religijne, zabawy i działania pobudzające rozwój dziecka $^{28}$. M. Posadzowa znała system M. Montessori i krytycznie odnosiła się do niego. Uważała, że „system ten wychowa sztucznie rozwiniętego, przedwcześnie dojrzałego mędrka. Jak owoc pędzony w cieplarni nie ma siły rozrodczej, tak dziecko tym systemem wychowane jest wewnątrz puste i zblazowane"29.

Na uwagę zasługuje także bogaty dorobek s. B. Żulińskiej ze Zgromadzenia Sióstr Zmartwychwstanek, w którym poświęciła się pracy pedagogicznej, zgodnej z jego charyzmatem. Wykorzystując swe doświadczenia pedagogiczne $\mathrm{w}$ pracy $\mathrm{w}$ przedszkolach, gruntownie zreformowała rodzaj prowadzonych zajęć. Napisała wiele książek dla dzieci, w których przybliżała najmłodszym prawdy wiary. Prowadziła również wykłady z dziedziny metodyki i pedagogiki, pisała artykuły na tematy wychowawcze. W swojej książce $K u$ zmartwychwstaniu ${ }^{30}$ przedstawiła katolicką myśl pedagogiczną i własne bogate doświadczenia w dziedzinie wczesnego wychowania ${ }^{31}$.

Irena Dudzińska zajmowała się badaniem procesu wychowania w przedszkolu i jego metodycznym wymiarem. Pod jej redakcją został wydany poradnik metodyczny oraz Metodyka wychowania w przedszkolu w trzech częściach jako prace zbiorowe ${ }^{32}$.

${ }^{27}$ S. M. Posadzowa, Instrukcje dla ochroniarek, Poznań-Warszawa-Wilno-Lublin 1930, okładka.

${ }^{28}$ Por. W. Leżańska, Wkład Stefanii Marciszewskiej-Posadzowej w rozwój pedagogiki przedszkolnej w Polsce, w: W. Jamrożek, D. Żołądź-Strzelczyk (red.), dz. cyt., s. 89-96.

${ }^{29}$ S. M. Posadzowa, dz. cyt., s. 3.

30 B. Żulińska, Ku Zmartwychwstaniu (zagadnienia pedagogiczne), Rzym 1950.

${ }_{31}$ Por. J. Kostkiewicz, Kierunki i koncepcje pedagogiki katolickiej w Polsce 1918-1939, Kraków 2013, s. 261-294.

32 I. Dudzińska, O wspólżyciu dzieci w grupie przedszkolnej, Warszawa 1970; I. Dudzińska (red.), Metodyka wychowania w przedszkolu, cz. I (1974), cz. II i cz. III (1976), Warszawa; Wychowanie i nauczanie w przedszkolu. Poradnik metodyczny, Warszawa 1983. Powstały we współpracy m.in. z M. Fiedler, J. Cybulską-Piskorek, S. Lipiną, H. Mystkowską, D. Malko. 
Procesem kształcenia nauczycieli w latach 70/80. zajmowały się między innymi Antonina Sawicka, Maria Fiedler, Ida Merżan - związane z redakcją czasopisma „Wychowanie w Przedszkolu”. A. Sawicka, uznając pedagogikę przedszkolną jako przedmiot, który łączy teorię z metodyką wychowania dzieci, opracowała podręcznik dla słuchaczy studium wychowania przedszkolnego. Jest także autorką licznych artykułów metodycznych oraz dotyczących zagadnień współpracy z rodzicami ${ }^{33}$. M. Fiedler pracowała jako pedagog i nauczyciel w Studium Nauczycielskim w Poznaniu. Zainteresowana szczególnie pracą z dziećmi na wsi oraz kształtowaniem pojęć matematycznych $\mathrm{w}$ wieku przedszkolnym poruszała te zagadnienia $\mathrm{w}$ artykułach i książkach ${ }^{34}$. I. Merżan była autorką książek i licznych artykułów, działaczką ruchu korczakowskiego, propagatorką jego myśli oraz metod wychowawczych i opieki nad dzieckiem ${ }^{35}$.

Współcześnie w różnych aspektach metodycznego wymiaru pedagogiki przedszkolnej wniosły swoje autorskie rozwiązania między innymi: Edyta Gruszczyk-Kolczyńska, proponując nauczycielom ciekawą koncepcję uczenia dzieci matematyki, Maria Kielar-Turska ${ }^{36}$ pokazała możliwości stymulowania mowy i języka, podkreślając znaczenie twórczej aktywności dzieci. Marta Bogdanowicz w trosce o wspomaganie rozwoju psychoruchowego dzieci rozwijała Metodę Dobrego Startu, prowadząc przez 10 lat zajęcia w gdańskich przedszkolach. Jest ona rezultatem ponad czterdziestoletnich doświadczeń w bezpośredniej pracy z dziećmi o prawidłowym i zaburzonym rozwoju psychoruchowym. Pierwsze próby jej opracowania podjęła w roku 1967/68, a podsumowanie tych doświadczeń opublikowała w 1985 roku w podręczniku ${ }^{37}$, uaktualnionym i wydawanym przez 24 lata w Wydawnictwach Szkolnych i Pedagogicznych ${ }^{38}$. Bogaty dorobek w dziedzinę metodyki wniosły Barbara Wlaźnik, Sabina Guz, a także znani badacze i badaczki pracujący na rzecz edukacji w przedszkolu ${ }^{39}$.

${ }^{33}$ Por. A. Sawicka, Wybór tekstów do ćwiczeń z pedagogiki przedszkolnej, Warszawa 1985, s. 3, 357; tenże, Z problematyki wychowania patriotycznego w przedszkolu, Warszawa 1980; tenże, Współpraca przedszkola z rodzicami, Warszawa 1978.

34 Por. tenże, Wybór tekstów, s. 355.

35 Por. tamże, s. 366.

${ }^{36}$ M. Kielar-Turska, Jak pomagać dziecku w poznawaniu świata, Warszawa 1992.

37 M. Bogdanowicz, Metoda dobrego startu, Warszawa 1985.

${ }^{38} \mathrm{http} / /$ www.martabogdanowicz.pl (25.10.2013)

39 D. Waloszek, Pedagogika przedszkolna, s. 70. 


\section{Kobiety rozwijające i doskonalące teorię wczesnej edukacji - pedagogikę przedszkolną}

Na podstawie rozwiniętych praktycznych systemów i form wczesnej edukacji $\mathrm{w}$ rodzinie $\mathrm{i}$ instytucjach pozarodzinnych oraz rozwiązań metodycznych i w odpowiedzi na nie kształtowała się stopniowo refleksja teoretyczna. Tu wielki wkład wniosły kobiety pośrednio zaangażowane w edukację małego dziecka, rozwijając i doskonaląc pedagogikę i teorię wczesnej edukacji - pedagogikę przedszkolną.

Jadwiga z Działyńskich Zamoyska (1831-1923) była teoretykiem pedagogiki katolickiej. Proces wychowania ujmowała jako nadawanie właściwego kierunku myślom, woli i uczuciom wychowanka. Wyłożyła spójną teorię wychowania zbudowaną na zasadach wiary katolickiej i akcentującą znaczenie czynnika wolitywnego. Na szczególną uwagę zasługuje jej nowatorski program szkoły pracy, w tym ukazanie realnej potrzeby i znaczenia - dla spełnienia życia indywidualnego, rodzinnego i narodowego - uczenia się pracy. Stworzyła swój program pracy wychowawczo-społecznej. W 1882 roku założyła w Polsce przeznaczoną dla dziewcząt i kobiet Szkołę Pracy Domowej. Szkoła miała na celu przygotowanie Polek do pełnienia obowiązków „,chrześcijańskich, narodowych i domowych”. Zdobywane w niej umiejętności praktyczne, sprawności intelektualne i duchowe miały wspomóc naród w odzyskaniu wolności ${ }^{40}$.

Dla rozwoju pedagogiki przedszkolnej jako subdyscypliny pedagogiki duże znaczenie ma dorobek naukowy, zarówno w dziedzinie różnych koncepcji pedagogiki, jak i jej historii. Znaczący wkład wniosły tu reprezentantki grona historyków wychowania, szczególnie oświaty i szkolnictwa, w którym wychowanie przedszkolne zostało uznane za pierwszy etap edukacyjny. Pionierkami naukowo zaangażowanymi były między innymi takie osoby, jak Hanna Pohoska, która wskazywała na przełomowe momenty w historii wychowania oraz na jej znaczenie w kształceniu nauczycieli. W dziejach wychowania ukazywała ideologiczne źródła tworzenia współczesnych koncepcji wychowawczych, podkreślała rolę pracy wychowawczej dla istnienia państwa i narodu oraz potrzebę kształcenia nauczycieli na rodzimym dorob-

${ }^{40}$ M. J. Gondek, Zamoyska Jadwiga (z Działyńskich), http://www.ptta.pl/pef/pdf/z/zamoyska.pdf (24.10.2013). 
ku historycznym z wykorzystaniem jego walorów wychowawczo-obywatelskich i ideowych ${ }^{41}$.

W zakresie badań i publikacji dotyczących historii wychowania przedszkolnego Sabina Lewinowa podjęła pierwszą próbę ukazania w miarę uporządkowanej genezy myśli i rozwiązań praktycznych w wychowaniu dzie$\mathrm{ci}^{42}$. Ujęła zagadnienie $\mathrm{w}$ trzech głównych działach: wychowanie fizyczne, do pracy i umysłowe dziecka w wieku przedszkolnym. Dostarczyła także wielu informacji o sposobie rozumienia dziecka, dzieciństwa i jego edukacji do początku lat 60 . XX wieku. Dla kształtowania pedagogiki ważne w przeprowadzonej analizie jest zwrócenie uwagi na znaczenie przeszłości w poszukiwaniu współczesnych rozwiązań oraz na konieczność zachowania refleksyjności i dystansu do rozwiązań obcych kulturowo. S. Lewinowa przestrzegała przed uproszczonym przenoszeniem ich na teren polskich potrzeb, z czego wynika wiele współczesnych błędów w pedagogice i co utrudnia rozwój rodzimej pedagogiki przedszkolnej. Pierwszy raz w powojennej historii Polski opisała zakres pojęciowy wychowania przedszkolnego, co jest bliskie współczesnej myśli o pedagogice wieku dziecięcego ${ }^{43}$.

Duży wkład w dorobek historii wychowania przedszkolnego wniosła Wanda Bobrowska-Nowak (1925-2003) ${ }^{44}$. W swoich badaniach koncentrowała się na tej tematyce w kontekście związków pedagogiki z psychologią, historią psychologii i pedagogiką opiekuńczą ${ }^{45}$. Irena Adamek swymi badaniami i publikacjami również przyczyniła się do wzbogacenia podstaw pedagogiki przedszkolnej w tym zakresie ${ }^{46}$.

Wkład kobiet ma także niemałe znaczenie w dorobku naukowym uwzględniającym i opisującym psychologiczny aspekt wychowania małego

${ }^{41}$ Por. W. Szulakiewicz, Hanna Pohoska jako historyk wychowania - między nauka, ideologiq a rzeczywistościq, w: W. Jamrożek, D. Żołądź-Strzelczyk (red.), dz. cyt., s. 111-116.

${ }^{42}$ S. Lewinowa, U poczatków polskiej teorii wychowania dziecka w wieku przedszkolnym, Warszawa 1960.

${ }^{43}$ Por. D. Waloszek, Pedagogika przedszkolna, s. 62-63.

${ }^{44}$ Opracowała podręcznik Zarys dziejów wychowania przedszkolnego, Warszawa 1977, wydany w 2 tomach: I - Teorie pedagogiczne i rozwój praktyki, II - Wybór materiałów źródłowych, a poszerzywszy jego zawartość wydała Historię wychowania przedszkolnego, Warszawa 1983.

45 P. Kowolik, Prof. zw. dr hab. Wanda Bobrowska-Nowak-pedagog i historyk wychowania, „Edukacja Ustawiczna Dorosłych” 1 (2003), s. 105-108.

${ }^{46}$ I. Adamek, Praktyka rozwojowa w wychowaniu małego dziecka, Kraków 1996; tenże, Przygotowanie dzieci do szkoly w rozwijajacym się systemie wychowania przedszkolnego na ziemiach polskich (II połowa XIX wieku - do 1918 roku), Kraków 1999. 
dziecka. Maria Przetacznik-Gierowska (1920-1995) jest autorką podręczników z zakresu psychologii rozwojowej i wychowawczej. Drugi obszar prowadzonych badań dotyczył zagadnień związanych z istotą i uwarunkowaniami rozwoju fizycznego, motorycznego i umysłowego dzieci ${ }^{47}$. Jadwiga Walczyna (1916-1991) w pracy naukowej zajmowała się teorią i modelem kształcenia akademickiego nauczycieli wychowania przedszkolnego i nauczania początkowego, także teorią zintegrowanego nauczania początkowe$\mathrm{go}^{48}$. Anna Brzezińska zajmuje się psychologicznymi podstawami edukacji, głównie dzieci, ale także ich rodziców i osób ważnych dla środowiska nauczycielskiego ${ }^{49}$. Współpracuje z redakcjami czasopism przeznaczonych dla rodziców i nauczycieli dzieci w wieku przedszkolnym ${ }^{50}$.

W miare postępu w badaniach psychologicznych i wzrostu zainteresowania organizowaniem planowego, instytucjonalnego wychowania dzieci, prowadzącego do lepszych efektów adaptacyjnych w szkole, rozwijały się pierwsze próby rozwoju pedagogiki przedszkolnej jako subdyscypliny pedagogiki. Wyniki badań nad dojrzałością szkolną, prowadzonych i opublikowanych pod kierunkiem B. Wilgockiej-Okoń ${ }^{51}$, przyczyniły się do rozwoju praktyki wychowania przedszkolnego i prób unaukowienia działalności wychowawczej wobec dzieci. Mimo wielostronności i istotności badań nie zaowocowały one jednak uogólnieniami w postaci syntetycznej pedagogiki przedszkolnej jako podręcznika akademickiego, czy ogólnie dostępnego dla praktyki. Rozpoczęły jednak w Polsce proces wyłaniania się pedagogiki przedszkolnej ${ }^{52}$.

${ }^{47}$ M. Przetacznik-Gierowska, Rozwój psychiczny dzieci i młodzieży, Warszawa 1967; tenże, Podstawy rozwoju psychicznego dzieci i młodzieży, Warszawa 1973; tenże, Świat dziecka, Kraków 1993; M. Przetacznik-Gierowska, Z. Włodarski, Psychologia wychowawcza, Warszawa 1994; M. Przetacznik-Gierowska, Psychologia rozwoju człowieka, Warszawa 1996; tenże, Rozwój struktury i funkcji zdań u dzieci w wieku przedszkolnym; M. Przetacznik-Gierowska, A. Kaczanowska, G. Makiełło-Jarża, Rozwój fizyczny, motoryczny i umysłowy dzieci i młodzieży, Warszawa-Kraków 1986.

48 J. Walczyna, Myślenie i działanie pedagogiczne - z badań nad procesem przygotowania młodzieży do zawodu nauczycielskiego, Warszawa 1966; tenże, Integracja nauczania poczqtkowego, Wrocław 1968; tenże, Kształtowanie postaw społeczno-moralnych dzieci w wieku przedszkolnym, Warszawa 1980.

49 A. Brzezińska, Psychologiczne portrety czlowieka. Praktyczna psychologia rozwojowa, Gdańsk 2005.

${ }^{50} \mathrm{http} / /$ eduentuzjasci.pl/pl/liderzy-projektu-3/611-prof-dr-hab-anna-izabela-brzezinska. html (24.10.2013).

${ }^{51}$ B. Wilgocka-Okoń, Dojrzałość szkolna a środowisko, Warszawa 1968.

52 D. Waloszek, Pedagogika przedszkolna, s. 63. 
Pedagogika przedszkolna wyrosła z pedagogiki jako jej subdyscyplina pod koniec lat 70. XX wieku. Z narastającymi potrzebami praktyki w 1968 roku ukazała się Metodyka wychowania przedszkolnego pod redakcją Marii Kwiatkowskiej i Zofii Topińskiej. Nie była to publikacja o charakterze naukowym, ale treści praktyczno-teoretyczne przedstawiały najważniejsze zadania i organizację rodzącej się subdyscypliny pedagogiki. Sześć lat później pojawiła się próba ukazania podstaw naukowo-teoretycznych subdyscypliny pod nazwą Pedagogika przedszkolna. Jednak mimo wyraźnie określonego w tytule odniesienia do ,pedagogiki”, autorki nie wyszły poza kwestie metodyczne ${ }^{53}$.

Począwszy od lat 80 . XX wieku powstawały wyspecjalizowane w teorii i metodyce wychowania dzieci jednostki naukowo-badawcze w uczelniach wyższych i wraz z nimi uruchamiano odpowiadające im kierunki studiów, kształcąc na nich teoretycznie i metodycznie przyszłych nauczycieli przedszkoli. Między innymi Danuta Waloszek od wielu lat zajmuje się badaniami ukierunkowanymi na rozwój pedagogiki przedszkolnej jako subdyscypliny pedagogiki ${ }^{5}$. Jej bogate doświadczenia $\mathrm{w}$ dziedzinie teorii edukacji najmłodszych i przekonanie o konieczności uwzględnienia dziecka i potrzeb dzieciństwa staje się swoistym przesłaniem. Wynika z niego twierdzenie, że

nakazem czasu współczesnego dla pedagogów przedszkolnych (teoretycznie i praktycznie zorientowanych) jest uporządkowanie metodologii, epistemologii i empirii, a także jasne określenie stosunku do przeszłości. Wskazanie układów odniesienia [...]; zarysowanie horyzontu zdarzeń przyszłych na tyle ogólnie, by nie więził w oczekiwaniach i standardach niemożliwych do przewidzenia, i na tyle szczegółowo, by dawał obraz możliwy do osiągnięcia przez dziecko pozwoli na określenie statusu i przedmiotu pedagogiki ${ }^{55}$.

\section{Zakończenie}

Bogaty dorobek w dziedzinie edukacji przedszkolnej wciąż pozostaje zdominowany przez metodykę, a praktyka pozbawiona jest głębszej reflek-

${ }^{53}$ Por. tamże, s. 63-64.

${ }^{54}$ Np. tenże, Przygotowanie dzieci sześcioletnich do zadań szkolnych, Zielona Góra 1993; tenże, Wychowanie najmłodszego człowieka, Zielona Góra 1996; tenże, Edukacja dzieci w wieku przedszkolnym, Zielona Góra 1996.

${ }_{55}$ Tenże, Pedagogika przedszkolna, s. 12. 
sji teoretycznej. Mimo akcentowanej mocno potrzeby zwrócenia uwagi na potrzeby dziecka i dzieciństwa oraz na znaczenie tego etapu dla rozwoju człowieka, nie powstają syntetyczne ujęcia i opracowania pedagogiki przedszkolnej. Mimo odwoływania się do zapisów aktualnej podstawy programowej wychowania, zawarte $\mathrm{w}$ niej propozycje dla praktyki tkwią w pedagogice lat 70. XX wieku ${ }^{56}$. Dając odpowiedź na dokonujące się w Polsce reformy oświatowe i wymagania dopasowania systemu oświaty do standardów Unii Europejskiej, poszerza się nieco teoretyczne podstawy edukacji przedszkolnej jedynie w zakresie oddziaływań metodycznych oraz wskazuje ściśle praktyczne rozwiązania łącznie ze scenariuszami zajęć57. Refleksje teoretyczne nad pedagogiką przedszkolną jako nauką pokazują, że spór o teoretyczność pedagogiki przedszkolnej trwa nadal.

Słuszne wydaje się przyjęcie dla rozwiązania współczesnego kryzysu wychowania idei pedagogiki w stanie tworzenia, z uwzględnieniem synergii praktyki i teorii wychowania przedszkolnego w Polsce ${ }^{58}$. Powrót do rodzimych koncepcji wczesnego wychowania realizowanych bądź rozwijanych przez zapomniane matki, wychowawczynie i nauczycielki, badaczki warunków wczesnej edukacji, praktycznie i teoretycznie w nią zaangażowane, może być niezbędnym źródłem inspiracji dla współczesnych rozwiązań. Pomogą one ukazać związki między wczesną edukacją a życiem osoby i społeczeństwa, między pracą wychowawczą a istnieniem narodu, między pedagogiką a filozofią i religią. Wtedy będzie możliwe postawienie pytań: kogo, dlaczego, kto i jak powinien wychowywać oraz udzielenie na te pytania konkretnej odpowiedzi.

Odpowiedź taka wymaga odniesienia do podstaw antropologicznych w refleksji nad człowieczeństwem dorosłych i dzieci. Uwzględnianie historycznego dorobku teoretyczno-praktycznego w zakresie rozwiązywania problemów wczesnej edukacji ,sprowokuje dalsze poszukiwania w przeszłości na rzecz teraźniejszości i przyszłości dzieciństwa i dziecka. To ważne zadanie dla każdego pedagoga. Czyli każdego, kto nie tylko zajmuje się wychowaniem, ale myśli o wychowaniu" 59 . Ważne jest tu uwzględnienie roli kobiet $\mathrm{i}$ ich zaangażowania naukowego $\mathrm{w}$ analizowanie i powracanie do do-

56 Por. tamże, s. 193-194.

57 Np. A. Klim-Klimaszewska, Pedagogika przedszkolna, Warszawa 2005; tenże, Pedagogika przedszkolna. Nowa podstawa programowa, Warszawa 2010.

${ }_{58}$ Taka próba została podjęta w: M. Opiela, Integralna pedagogika przedszkolna $w$ systemie wychowania Edmunda Bojanowskiego. Kontynuacje i zamiany, Lublin 2013.

59 D. Waloszek, Pedagogika przedszkolna, s. 12. 
świadczeń dziejowych, o czym świadczy także ich miejsce w historiografii oświatowej ${ }^{60}$. W tym kontekście jawi się ich szczególna rola we wczesnej edukacji, w twórczym rozwijaniu rodzimych rozwiązań i kultywowaniu tradycji wychowawczych oraz pedagogiki przedszkolnej.

\section{Development of the Early Childhood Education Theory and Practice in Poland in the 19th and 20th Centuries (Summary)}

The development of preschool education is a process of transition from the practical experience to much more scientific education of a small child. Its origins as a sub-discipline of education are found in the 70 s of the twentieth century. Still, this beginning is preceded by the considerable achievements of many generations of education theorists and practitioners. It is only a part of the process that is still ongoing. However, the women's contribution to this process is hardly emphasized, and yet they have contributed to the development of native thought, practice and foundations of the early childhood education theory. The purpose of this article is to show the specific contribution of women, who are directly and indirectly involved in the young child education, as well as development and improvement of the early education theory bases - preschool education.

Keywords: female, instructor, the teacher, early childhood education, preschool education

\section{Wkład kobiet w rozwój teorii i praktyki wczesnej edukacji w Polsce XIX i XX wieku (Streszczenie)}

Rozwój pedagogiki przedszkolnej jest procesem przechodzenia od doświadczeń praktycznych po unaukowienie edukacji małego dziecka. Jej początki jako subdyscypliny pedagogiki określa się na lata 70 . XX wieku. Wskazany początek poprzedza jednak ogromny dorobek wielu pokoleń teoretyków i praktyków wychowania. Jest on jedynie elementem procesu, który wciąż trwa. Rzadko jednak zwraca się uwagę na rolę kobiet $\mathrm{w}$ tym procesie, a przecież przyczyniły się do kształtowania

${ }^{60}$ Por. W. Szulakiewicz, Historia oświaty i wychowania w Polsce 1918-1939, Toruń 2000, s. 172-174. 
rodzimej myśli, praktyki i podstaw teorii wczesnej edukacji. Celem niniejszego artykułu jest ukazanie szczególnego wkładu kobiet bezpośrednio i pośrednio zaangażowanych w edukację małego dziecka w rozwój i doskonalenie podstaw teorii wczesnej edukacji - pedagogiki przedszkolnej.

Słowa kluczowe: kobieta, wychowawczyni, nauczycielka, wczesna edukacja, pedagogika przedszkolna 
